\title{
IMPLEMENTASI FUNGSI PENGAWASAN PENYIARAN PROGRAM MUSIK DANGDUT OLEH KPID JAWA TIMUR
}

\author{
Nur Fathin Luaylik dan Nanik Kusumiati Hudaya \\ Program Studi Ilmu Administrasi Negara, FIA, Universitas Madura \\ Jl. Raya Panglegur KM. 3,5 Pamekasan \\ Email : nurfathinluaylik@yahoo.com
}

\begin{abstract}
The Formation Of Komisi Penyiaran Indonesia (KPI) on 2002 based on policy regulation No 32, 2002 as independent instution or regulatory on broadcasting, in central and district level. Today in realitity more published dangdut talent show program. This fact make be challenge to implemented policy regulation No.32, 2002 about broadcast. One of main KPI role to supervise of broadcast but still violation happen mainly about content of broadcast. This research aims is to analyse about KPID exixtence East Java given to zise of dangdut program broadcast published. This research is descriptive kualitative. The theory this research use implementation theory from George Edward III with four indicator communication, disposition, bureaucracy structure and main resource. The Result this research show obstacle factor to implemented of policy regulation No. 32, 2002 is limited of facility, so that impmenting of regulation policy not too maximum.
\end{abstract}

Keywords: Implementation, KPID, Dangdut.

Abstrak: Komisi Penyiaran Indonesia (KPI) terbentuk pada tahun 2002 berdasarkan Undang-Undang No. 32 Tahun 2002 tentang penyiaran. Lembaga independen ini menjadi regulator dalam bidang penyiaran baik di tingkat pusat maupun daerah. Kenyataannya saat ini semakin bermunculan program pencarian bakat penyanyi dangdut. Hal ini menjadi tantangan untuk mengimplementasikan Undang-Undang No. 32 Tahun 2002 tentang penyiaran. Salah satunya KPI memiliki peran utama sebagai implementor Undang-Undang tersebut. Adanya KPI sebagai lembaga independen untuk mengawasi penyiaran, pelanggaran masih terjadi terutama dalam sajian serta isi siaran. Oleh karena itu, tujuan penelitian ini, yaitu menganalisa mengenai eksistensi KPID Jawa Timur terhadap pemberian porsi alokasi penyiaran program musik. Jenis penelitian yaitu deskiptif kualitatif. Teori yang digunakan dalam peneltian ini yaitu teori implementasi kebijakan George Edward III dengan indikator komunikasi, disposisi, struktur birokrasi dan sumber daya. Hasil penelitian menunjukkan adanya faktor penghambat dalam implementasi UU No. 32 tahun 2002 yaitu keterbatasan berbagai sarana prasarana sehingga implementasi berjalan hanya dengan mengandalkan sumber daya yang ada.

Kata Kunci: Implementasi, KPID, Dangdut.

\section{PENDAHULUAN}

Perjalanan Dangdut di dunia musik Indonesia sudah mengalami berbagai dinamika, tantangan maupun fase puncak kejayaan. Dangdut sampai sekarang masih menempati posisi dominan di hati penikmat musik Indoenesia . Mulai dari kalangan "gedongan" sampai golongan "proletar". Kondisi inilah maka Dangdut dianggap sebagai musik asli Indonesia. Dangdut menjadi "sangat akrab" di berbagai acara hajatan, pesta rakyat bahkan 
acara-acara bergengsi lainnya, seakan-akan tidak semarak jika tidak menggunakan Dangdut untuk memeriahkan suasana.

Sebelum Dangdut dikenal ,penyebutan "Musik Melayu." Lahirnya dua istilah ini dipengaruhi berbagai pengaruh kesenian Arab, India dan Melayu pada tahun 1940-an (Piper dan Jabo, hal. 9). Berawal dari penggunaan istilah Musik Melayu, kemudian Melayu Deli sampai Dangdut.

Istilah Musik Melayu digunakan dan dikenalkan oleh Dr. A. K. Gani tahun tokoh Partai Serikat Islam Indoensia (PSII) tahun 1938 ketika memperingati hari sumpah pemuda. Dimana hiburan yang digunakan adalah musik keroncong. Walaupun Usaha Dr. A.K Gani belum berhasil untuk menanamkan pemahaman Musik Melayu murni karena banyak orang menganggap irama keroncong merupakan bentuk perlawanan pada karakter bangsa Barat dan Cina.(Frederick, Jurnal Indonnsia No. 34, Oktober 1982, hal. 106).

Pada tahun 1940-an cikal bakal Dangdut mulai terlihat dengan pengaruh unsur Arab, Parsi dan Musik melayu. Namun pengaruh berbagai jenis musik terhadap musik Dangdut belum sepenuhnya sesuai dengan kondisi negara dimana saat itu masih memperjuangkan kemerdekaan. Kondisi inilah menyebabkan cikal bakal Dangdut sempat "terhenti" karena lebih banyak lagu bernuansakan nasionalisme daripada sekedar musik Melayu.

Disnilah terlihat peran serta media penyiaran, dimana pada periode tertentu, Radio Republik Indonesia (RRI) menjadi satu-satunya radio pemerintah. RRI memberikan banyak porsi penyiaran terhadap jenis musik nasional. Dalam waktu bersamaan RRI, Radio Angkatan Udara juga sering menyiarkan koleksi piringan hitam yang didominasi pengaruh "barat" seperti Bing Crosby, Perry Como, Doris Day dan Johny Ray, (Piper dan Jabo,1987, hal. 9).

Namun niatan menumbuhkan rasa nasionalisme, malah menuai kondisi dan reaksi berbeda. Pemberian porsi terhadap pemutaran musik "barat" memancing ketakutan pemerintah terhadap pengaruh Barat. Akibatnya muncul larangan memutar musik barat, sehingga menjadi kesempatan Musik Melayu mendapatkan porsi penyiaran lebih banyak karena dianggap penampilan penyanyi Melayu lebih sopan dan rapi, sehingga masa ini merupakan puncak kejayaan Musik Melayu .

Proses selanjutnya awal tahun 1955 Musik Melayu akhirnya identik dengan "Melayu Deli". Istilah Melayu Deli sangat beralasan pasalnya dilihat dari asal usul Musik Melayu dari Deli dan proses perkembangan selanjutnya terjadi di wilayah Indonesia (Kesumah, dkk, hal. 27). Pada saat bersamaan sebetulnya istilah "Melayu Deli" merupakan cikal bakal penyebutan musik Dangdut. Karena Melayu Deli dianggap lebih identik ke pengaruh Melayu, hanya saja penggunaan istilah Dangdut belum digunakan.

Berbeda dengan masa kontemporer dimana Dangdut mengalami perubahan baik dari segi pertunujukan, syair lagu dan bermunculan berbagai ajang pencarian bakat penyanyi-penyanyi Dangdut. Dangdut mulai mengalami perubahan besar dari segi penyajian khususnya nuansa penyiaan dan pertunjukan.

"Dangdut is the music of my country" merupakan salah satu penggalan lagu grup musik Project Pop mencoba menjelaskan betapa akrabnya Dangdut di hati penikmat musik Indoesia. Identitas "merakyat" dan menembus batasan tembok pembatas selera jenis musik adalah ciri Dangdut. Melalui "celotehan" lucu grup project pop menjadi gambaran bahwa begitu luasnya sisi Dangdut mampu memberikan hegemoni penggemarnya maupun yang "anti Dangdut”. 
Pergeseran status musik Dangdut dari musik rakyat "bawahan" menjadi “ gedongan" tidak terepas dari regulasi serta peran serta kebijakan pemerintah, terutama bidang penyiaran. Kebijakan pemerintah sekarang menjadikan Dangdut memiliki kiprah semakin luas dan mampu menjadi sumber atau pundi rupiah terutama bagi pencipta lagu, produser, komposer terutama penyanyi. Pelaku seni berlomba-lomba mempersembahkan karya terbaik supaya bisa diterima oleh masyarakat luas. Sekarang seolah-olah muncul istilah yang menggambarkan kondisi dangdut "dangdut dalam rupiah".

Regulasi pemerintah sangat terlihat dalam kiprah Musik Melayu, akhirnya disebut Dangdut. Saat ini Dangdut menempati porsi penyiaran setara dengan jenis musik lainnya. Bermunculan berbagai acara televisi menyiarkan nuansa Dangdut secara professional menjadi ladang kesempatan baru bagi penggiat serta penyanyi Dangdut. Munculnya berbagai acara Dangdut membawa dampak positif serta perubahan taraf hidup pelaku Dangdut. Perubahan nasib menjadi lebih mewah banyak dialami penyanyi dangdut ketika kemunculannya di ajang pencarian bakat penyanyi Dangdut.

Diawali dengan adanya program joged di RCTI awal tahun 2000-an, dimana menyajikan hiburan bernuansa Dangdut modern. Tidak sampai disini program selanjutnya yaitu Kontes Dangdut Indonesia (KDI) di TPI tahun 2004 dimana Dangdut mulai dikemas dalam bentuk kompetisi bagi para penyanyi Dangdut. Semakin hari banyak bermunculan ajang pencarian bakat di stasiun televisi swasta yaitu di Indosiar, mencoba mengemas Dangdut dalam acara ajang pencarian bakat Kondang In. Bahkan sampai sekarang Indosiar sepertinya menjadi stasiun televisi swasta yang selalu menyajikan program pencarian bakat bagi penyanyi dangdut secara berkelanjutan. Mulai dari acara D'Academy 1 sampai 4, D'Acadey Asia 1 dan 2, dan D'Academy Celebrity. Dimana semua program pencarian bakat ini disiarkan secara langsung setiap hari. Tidak tanggung-tanggung pelaksanaannya sampai beberapa bulan, sehingga juga memberikan pengaruh kepada siapa yang menyaksikannya.

Berbagai acara ajang pencarian bakat penyanyi dangdut dikemas secara modern semakin bermunculuan, dianggap merupakan wujud batu loncatan bagi penyanyi dangdut. Tidak jarang menjadi media merubah kondisi hidup dan sumber pundi-pundi rupiah. Melalui ajang inilah posisi penyayi dangdut memiliki kesetaraan dengan penyanyi jenis musik lain, bahkan membawa nuansa berbeda dangdut menjadi "pantas" dianggap musik "gedonngan" Dangdut tampil tidak hanya sebagai musik kaum kalangan "bawah" namun sebagai jenis musik tanpa adanya batasan kelas penikmatnya. Melalui ajang pencarian bakat ini membawa dampak perubahan, Dangdut mulai tampil sebagai jenis musik elegan, serta memiliki daya tarik setara dengan jenis musik lainnya.

Semakin bergesernya posisi dan status musik Dangdut membuat banyak artis tertarik menekuni dangdut sebagai sumber pundi-pundi rupiah. Bahkan seolah-olah tidak muncul lagi istilah "Dangdut itu bukanlah music yang mampu menghibur hati". Bermunculannya berbagai ajang pencarian bakat ini memiliki dua sisi dampak, sebagai sarana pengembangan eksistensi musik Dangdut dan tidak menutup kemungkinan menjadi media terjadinya berbagai pelanggaran dalam bentuk konten penyiaran. Sehingga memerlukan adanya lembaga independen murni yang mengawasi baik dari proses, isi, porsi maupun etika penyiaran.

Undang-Undang Penyiaran Nomor 32 Tahun 2002 merupakan dasar pembentukan Komisi Penyiaran Indonesia (KPI). Tujuan pengelolaan sistem penyiaran, merupakan ranah publik harus dikelola sebuah badan independen yang bebas dari campur tangan pemodal 


\section{REFORMASI}

ISSN 2088-7469 (Paper) ISSN 2407-6864 (Online)

Volume 8 Nomor 2 (2018)

maupun kepentingan kekuasaan. Berbeda dengan semangat dalam Undang-Undang penyiaran sebelumnya, yaitu Undang-Undang No. 24 Tahun 1997 pasal 7 yang berbunyi "Penyiaran dikuasai oleh negara yang pembinaan dan pengendaliannya dilakukan oleh pemerintah", menunjukkan bahwa penyiaran merupakan bagian dari instrumen kekuasaan digunakan untuk semata-mata bagi kepentingan pemerintah.

Kenyataannya saat ini semakin bermunculan program pencarian bakat penyanyi Dangdut. Kondisi ini menyebabkan tantangan dalam implementasi Undang-Undang No. 32 Tahun 2002 tentang penyiaran. Salah satunya Komisi Penyiaran Indonesia (KPI) memiliki peran utama sebagai implementor Undang-Undang tersebut. Adanya KPI sebagai lembaga independen dalam mengawasi penyiaran tetap terjadi pelanggaran terutama dalam sajian serta isi siaran. Sehingga kondisi meningkatnya potensi pelanggaran diperlukan pengawasan baik dari isi siaran kemudian dilanjutkan dengan penindakan isi pelanggaran.

\section{TINJAUAN PUSTAKA}

Teori Implementasi Geoge C. Edward III

Geoge C. Edward III mencetuskan model implementasi kebijakan yang berspektif top down dipengaruhi oleh empat variabel yaitu (1) komunikasi, (2) Sumberdaya,(3) disposisi dan (4) struktur birokrasi.

\section{Komunikasi}

Implementasi kebijakan publik agar dapat mencapai keberhasilam, mensyaratkan agar implwmntator mengetahui apa yang harus dilakukan secara jelas. Apa yang menjadi tujuan dan sasaran kebijakan harus diinfomasikan kepada kelompok sasaran (target group) sehingga akan mengurangi distorsi implementasi. Sehinga perlu melakukaniga hal yaitu (1) penyaluran (transmisisi yang baik akan menghasilkan implemntasi yang baik pula kejelasan, (2) adanya kejelasan yang diterima oleh pelaksana kebijakan dan (3) adanya konsistensi yang diberikan dalam pelaksanaan kebijakan. Jika yang di komunikasika berubah-ubah akan membingungkan dalam pelaksanaan kebijakan yang bersangkutan.

2. Sumberdaya.

Implementasi kebijakan mutlak memerlukan dukungan sumbedaya baik sumber daya manusia, matrial dan metoda. Isi, sasaran dan tujuan kebijakan walaupun sudah dikomunikasikan secra jelas dan konsisten, tetapi apabila implemntator kekurangan sumber daya untuk melaksanakan, implemntasi tidak akan tidak berjala efektif dan efisien.

3. Disposisi.

Suatu disposisi dalam implemntasi dan karakteristik, sikap yang dimiliki oleh implementator kebijakan, seperti komitmen, kejurjuran, komunikatif, cerdik dan sifat demokratis. Disposisi yang baik arus dimiliki implemntator supaya bisa menjalankan kebijakan dengan bak seperti pa yang diinginkan dan ditetapkan pembuat kebijakan. 


\section{REFORMASI}

ISSN 2088-7469 (Paper) ISSN 2407-6864 (Online)

Volume 8 Nomor 2 (2018)

\section{Gambar 1}

Indikator Implementasi Menurut George Edward III

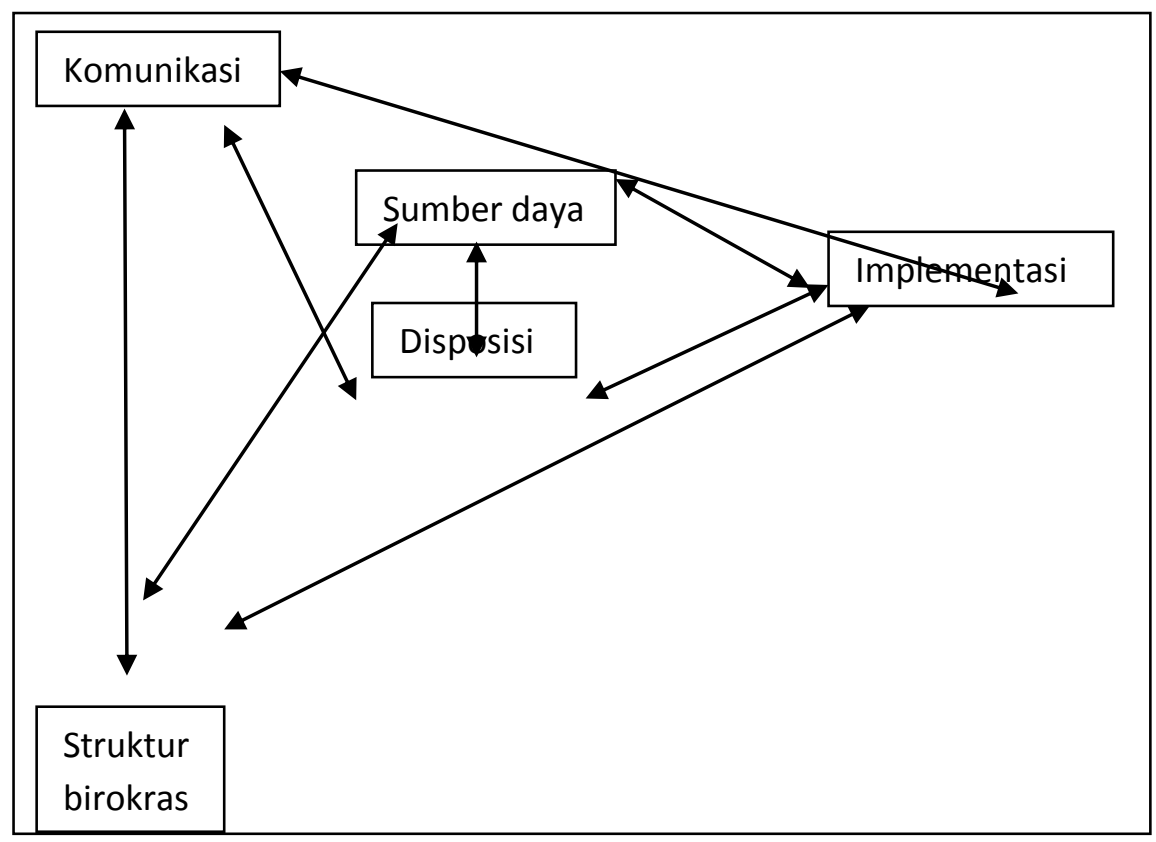

Sumber :Edward III(1980) dalam Nawawi,2007:138

\section{Struktur birokrasi.}

Organisasi, menyediakan peta sederhana untuk menunjukkan secara umum kegiatan-kegiatannya dan jarak dari puncak menunjukka status relatifnya. Garisgaris antara berbagai posisi dibingkai untuk menunjukkan interaksi formal yan ditetapkan. Kebanyakan peta organisasi bersifat hirarkis dan menentukan hubungan antara atasan dan bawahan secara diagonal langsung organisasi sebagai melalui lima hal harus tergambar yaitu (a) Jenjang hirarki jabatan- jabatan manajerila yang jelas sehingga terlihat" siapa yang bertanggungjawab kepada siapa", (b) Pelembagaan berbagai jenis kegiatan operasional sehingga nyata jawaban terhadap ertanyaan :"siapa yang" melakukan apa?",(c) Jaringan informasi yang dapat dignakan untuk berbagai kepentingan, baik yang sifatnya instistusional maupun individual,(d) hubungan antara satu sauna kerja dngan berbagai satuan kerja yang lain.(Nawawi, 2007:136-138)

\section{Model Proses Implementasi Kebijakan}

Meer dan Horn mencetuskna teori mengenai proses implemntasi dipengaruhi sifat kebijaksanaan yang akan dilaksanakan. Kemudian menghubungkan isu kebijaksanaan dengan implementasi yang kemudian akan mwnghubungkan antara kebijaksanaan dengan prestasi kerja. Konsep mengenai perubahan, kontrol dan kepatuhan bertidak merupakan konsep-konsep penting dalam prosedur-prosedur implemntasi. Sehingga pembahasan mengarah kepada hambatan-hambatan yang terjadi dalam mengenakan perubahan dalam organisasi, efektifitas mekanisme-mekanisme kontrol ada setiap jenjang struktur serta seberapa besar ketertarikan masing-masing orang dalam rganisasi. (Wahab,2001:78-79)

Sehingga, Meter dan Horn mengklasifikasikan tipologi kebijaksanaan yaitu (1) jumlah masing-masing perubahan yang akan dilaksanakan dan (2) Jangkauan atau lingkup kesepakatan terhadap tujuan diantara pihak-pihak yang erlibat dalam proses implemntasi. 


\section{REFORMASI}

ISSN 2088-7469 (Paper) ISSN 2407-6864 (Online)

Volume 8 Nomor 2 (2018)

Ada enam variable yang mempengaruhi kinerja implementasi yakni (1) standar dan sasaran kebijakan, (2) sumberdaya, (3)Komunikasi antar organisasi dan penguatan aktivitas,(4) karektaristik agen pelaksana, (5) dispoisisi implementor (6) lingkungan kondisi sosial, ekonomi dan politik. Diman hubungan keenam variable bisa dijelaskan melalui gambar model implemntasi.

Gambar II.2

Model Implementasi Kebijakan Menurut Van Meter \& Van Horn

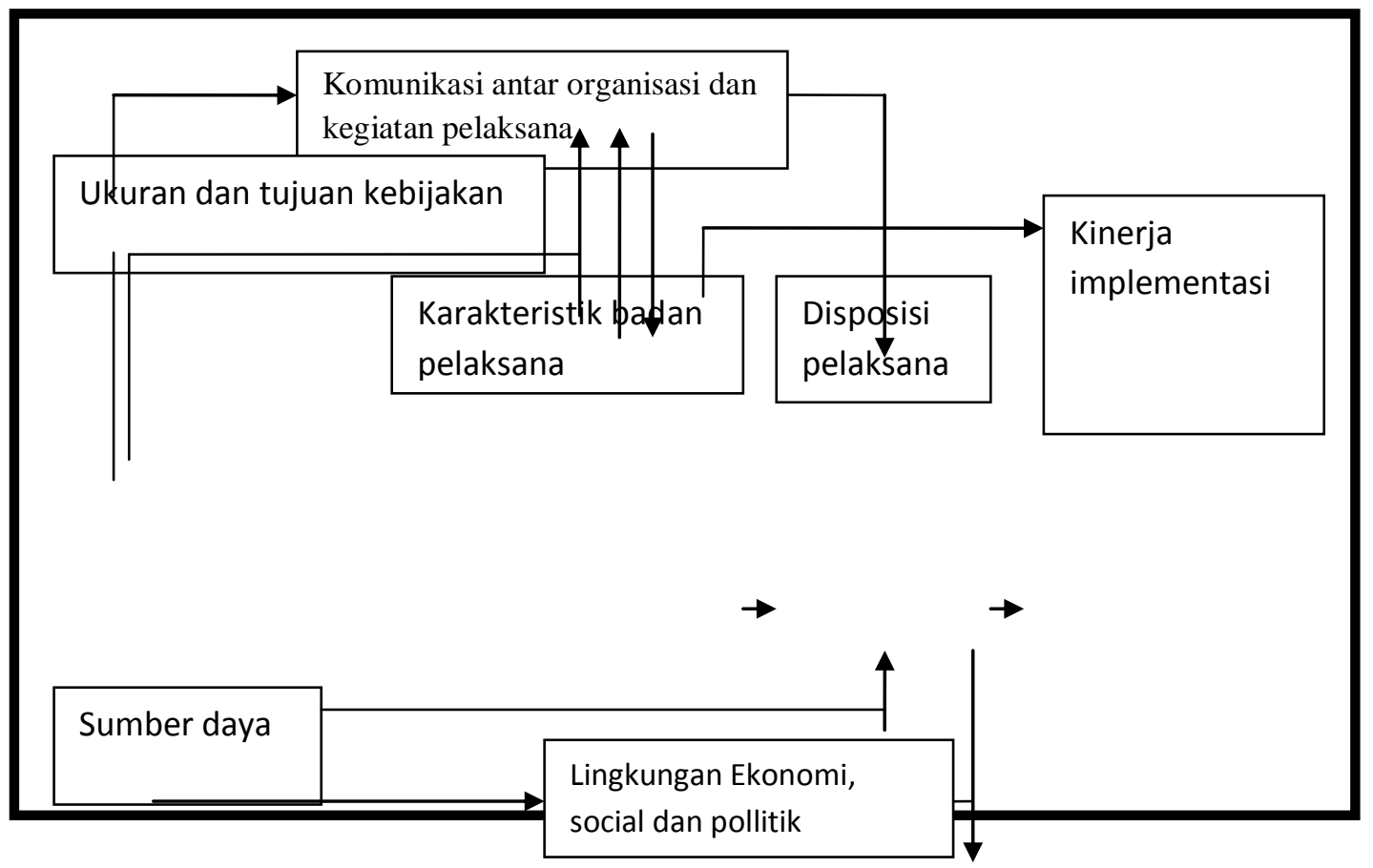

Sumber : Van meter dan Horn (1975) dalam Nawawi(2007:140)

1. Standard sasaran kebijakan.

Setiap kebijakan publik hars mempunyai standart dan suatu sasaran kebijakan jelas dan erukur. Dengan ketentuan tersebut tujuannya dapat terwujudkan. Dala, standard an sasaran kebijakan tidak jelas, sehingga tidak bisa terjadi multi interpretasi dan mudah menimbulkan keslahpahaman dan konflik diantara para agen implementasi

2. Sumberdaya implementasi.

Dalam suatu implementasi kebijakan perlu dukungan sumberdaya baik sumberdaya manusia (human resources) ,maupun sumber daya material (matrial resources) dan sumber daya metoda ( method resources). Dari ketiga sumber daya tersebut, yang paling penting adalah sumber daya manusia, karena disamping sebagai subjek implementas kebijakan juga termasuk objek kebijakan publik.

3. Komunikasi antar organisasi. Mewujudkan implementasi suatu program diperlukan hubungan baik antara antar instansi yang terkait yaitu dukungan komunikasi dan koordinasi. Kordinasi dan komunikasi merupakan nadi sebuah organisasi supaya programnya dapat terealisasi dengan tujuan serta sasarannya.

4. Karakteristik agen pelaksana.

Dalam suatu implemntasi kebijakan agar mencapai keberhasilan maksimal harus diidntifikasikan dan diketahui karakteristik agen pelaksana yang mencakup struktur 


\section{REFORMASI}

ISSN 2088-7469 (Paper) ISSN 2407-6864 (Online)

Volume 8 Nomor 2 (2018)

birokrasi, norma-norma dan pola hubungan yang terjadi dalam birokrasi , semua itu akan mempengaruhi implementasi suatu program kebijakan yang telah ditentukan.

5. Disposisi implemnetator.

Ada tiga sikap implemnetator yaitu (1) respon implementor terhadap kebijakan, terkait dengan kemauan implementor untuk melaksanakan kebijakan publk, (2) kondisi, yakni pemahaman terhadap kebijakan yang telah ditetapkan dan (3) intensitas disposisi implementor yakni prefrensi nilai yang dimiliki tersebut.

6. Kondisi lingkungan sosial, politik dan ekonomi.

Variabel ini mencakup sumber daya ekonomi lingkungan yang dapat mendukung keberhasilan implemntasi kebijakan, sejau mana kelompok-kelompok kepentingan memberikan dukungan bagi implementasi kebijakan, karakteristik ara partisipan yakni mendukung atau menolak; bagaimana sifat opini publik yang ada di lingkungan dan apakah elit politik mendukung implemntasi kebijakan

Dalam peneltian ini menggunakan analisa implementasi kebijakan model top down yang dicetuskan oleh Brian W. Hogwood dan Lewis A. Gunn (1978;1986). Teori implementasi kebijakan milik George Edward III dengan indikator 1.Komunikasi, 2. Disposisi, 3. Struktur Birokrasi dan (4) sumber daya. Dimana implementasi pengawasan tehadap eksistensi musik dangdut berdasarkan Undang-undang No.32 Tahun 2002 memerlukan berbagai komponen supaya implemntasi bisa berjalan sesuai target kebijakan, memberikan pengaruh antara kondisi sebelum dan setelah diimplementasikan, serta mengetahui apa saja faktor penghambat dan pendukung implementasi kebijakan.

\section{Pengawasan Penyiaran}

Menurut Handoko (2001: 373) untuk menjadi efektif, sistem pengawasan harus memenuhi kriteria tertentu. Kriteria-kriteria utama adalah bahwa sistem seharusnya mengawasi kegiatan-kegiatan yang benar, tepat waktu, dengan biaya yang efektif, tepatakurat dan dapat di terima oleh yang bersangkutan. Semakin di penuhinya kriteria-kriteria tersebut semakin efektif sistem pengawasan. Karakteristik-karakteristik pengawasan yang efektif dapat lebih di perinci sebagai berikut :

1. Akurat

Informasi tentang pelaksanaan kegiatan harus akurat. Data yang tidak akurat dari sistem pengawasan dapat menyebabkan organisasi mengambil tindakan koreksi yang keliru atau bahkan menciptakan masalah yang sebenarnya tidak ada.

2. Tepat Waktu

Informasi harus di kumpulkan,di sampaikan dan di evaluasi secepatnya bila kegiatan perbaikan harus di lakukan segera.

3. Obyektif dan menyeluruh Informasi harus mudah di pahami dan bersifat obyektif serta lengkap.

4. Terpusat pada titik-titik pengawasan strategik

Sistem pengawasan harus memusatkan perhatian pada bidang-bidang di mana penyimpangan-penyimpangan dari standar paling sering terjadi atau yang akan mengakibatkan kerusakan paling fatal.

5. Realistik secara ekonomis

Biaya pelaksanaan sistem pengawasan harus lebih rendah, atau paling tidak sama dengan kegunaan yang di peroleh dari sistem tersebut. 
REFORMASI

ISSN 2088-7469 (Paper) ISSN 2407-6864 (Online)

Volume 8 Nomor 2 (2018)

6. Realistik secara organisasional

Sistem pengawasan harus cocok atau harmonis dengan kenyataan-kenyataan organisasi.

7. Terkoordinasi dengan aliran kerja

organisasi Informasi pengawasan harus terkoordinasi dengan aliran kerja organisasi, karena setiap tahap dari proses pekerjaan dapat mempengaruhi sukses atau kegagalan keseluruhan operasi, dan informasi pengawasan harus sampai pada seluruh personalia yang memerlukannya.

8. Fleksibel

Pengawasan harus mempunyai fleksibilitas untuk memberikan tanggapan atau reaksi terhadap ancaman ataupun kesempatan dari lingkungan.

9. Bersifat sebagai petunjuk dan operasional

Sistem pengawasan efektif harus menunjukkan baik deteksi atau deviasi dari standar dan tindakan koreksi apa yang seharusnya di ambil.

10. Diterima para anggota organisasiSistem pengawasan harus mampu mengarahkan pelaksanaan kerja para anggota organisasi dengan mendorong perasaan otonomi, tanggung jawab dan berprestasi

Dari beberapa karakter pengawasan terhadap penyiaran, maka bisa dianalisa dan disimpulkan bahawa pengawasan penyiaan bukan hanya tentang bagaimana mengetahui berbaga pelanggaran, bagaimana mengkur pelanggaran sehingga menentukan sanksi yan akan diberikan. Namun ada beberapa karakter yang aruds dipenuhi pengawasan itu sendiri supaya bisa berjalan optimal dan efisien. Baik dalam bentuk kerjasama lembaga penyiaran maupun kondisi sasaran pengawasan supaya kegiatan pengawasan memberikan dampak bagi sasaran kegiatan.

\section{METODE PENELITIAN}

Berdasarkan tujuan penelitian, penelitian ini termasuk jenis penelitian deskriptif. Jenis penelitian deskriptif ini sesuai dengan tujuan penelitian, yaitu untuk menganalisa mengenai implemnetasi Undang-undnag No.32 Tahun 2002 dlam segi pengawasan tentang penyiaran oleh KPI terhadap eksistesi music dangdut. Analisa pengawasan lebih mengarah kepada bagaimana isi dari penyiaran program musik dangdut yang semakin memiliki porsi pernyiaran besar dalam ranah hiburan masyarakat. Sehingga dengan pemberian porsi penyiaran besar terhadap program pencarian bakat musik dangdut bisa dianalisa bagaimana implementasi Undang-undang No.32 Tahun 2002 bisa berpartisipasi meningkatkan kualitas isi penyiaran serta penindakan ketika terjadi pelanggaran isi siaran musik dangdut. Observasi langsung dilakukan terhadap bagaimana implemnetasi UndangUndang No.32 Tahun 2002 tentang penyiaran di Kantor KPID Jawa Timur, Surabaya. Observasi ini dilakukan karena banyaknya berbagai penyiaran pogram musik Dangdut baik di televisi nasional maupun daerah. Sedangkan KPID merupakan lembaga independen penyiaran di Daerah yang memiliki wewenang dalam menganalisa, mengklasifikasi serta pemberian sanksi terhadap segala bentuk pelanggran penyiaran. Dimana posisi KPID Jawa Timur merupakan lembaga independen yang beregerak dalam bidang penyiaran, sehingga tingkat subjektifitas ketika melakukan penindakan pelanggaran bisa dinetralisir.

Pengambilan data pewawancara tersebut bertujuan menggali data berhubungan dengan implementasi kebijakan dalam eksistensi Musik Dangdut studi pengawasan Undang-Undang No. 32 tahun 2002 terntang penyiaran terhadap bentuk pelanggraan isi 
penyiaran program pecarian bakat musik dangdut. Selain itu peneliti juga ingin menggali informasi megenai opini akan diberikan penggiat dangdut terhadap segala bentuk pelanggaran isi penyiaran program musik Dangdut. Berdasarkan pernyataan inilah nantinya akan di analisa pengaruhnya terhadap suasna pertunjukan dan penyiaran musik Dangdut.

Studi dokumentasi, merupakan metode pengumpulan data mengenai gambaran umum mengenai implementasi Undang-undang No.32 Tahun 2002 dalam melaksanakan fungsi pengawasan terhadap eksistensi musik dangdut. Data dokuemntasi berasal dari hasil wawancara antara penelitia dengan kordinator bidang penindakan pelanggaran isi siaran (P2IS). Data dokumentasi berupa penjelasan mengenai pola komunikasi, disposisi, struktur birokrasi dan sumber daya dimana merupakan indikator teori implementasi dariGeorge Edward III. Sehingga penjelasan dilakukan. Salah satunya mengenai bagaimana keseharian pelaksanaan implementasi UU No. 32 Tahun 2008 terhadap segala bentuk pelanggaran isi siaran program music dangdut.

\section{PEMBAHASAN}

\section{A. Implementasi Fungsi Pengawasan Penyiaran Program Musik Dangdut oleh KPID Jawa Timur}

Implementasi kebijakan terutama dalam bidang pengawasan isi siaran maka peneliti menggunakan teori implementasi kebijakan milik George Edward III. Alasan peneliti memilh menggunakan teori ini karena indikator teori relevan dengan masalah penelitian dimana analisa diakukan dengan menggunakan indikator teori sampai menemukan kesimpulan dari permasalahan penelitian.

Teori implementasi dari Geoge C. Edward III lebih mengutamanakan analisa komponen pelaksanaan kebijakan. Bukan hanya dari sektor pencipta kebijakan (policy maker),proses pelaksanaan bahkan model interaksi antar komponen menjadi sasaran menjadi pembahasan juga. Sehingga hasil analisa implementasi lebih menyeluruh dibandingkan penggunaan teori implemetasi lainnya. Sehingga implementasi Undangundang No.32 Tahun 2002 bukan hanya dikaji dari sisi pelaksana kebijakan namun lebih kepada bagaimana kaitan antara kondisi lapangan dengan penerapan peraturan penindakan pelanggaran isi siaran tersebut dilaksanakan.

Teori implementasi Geoge C. Edward III memiliki perspektif pelaksanaan kebijakan tipe topdown dipengaruhi beberapa indikator yaitu (1) komunikasi, (2) Sumberdaya,(3) disposisi dan (4) struktur birokrasi.

\section{a. Komunikasi,}

Implementasi kebijakan publik agar dapat mencapai keberhasilan, mensyaratkan agar implementor mengetahui yang harus dilakukan secara jelas. Tujuan utama dan sasaran kebijakan harus diinformasikan kepada kelompok sasaran (target group) sehingga akan mengurangi distorsi implementasi. Sehinga perlu melakukan tiga hal yaitu (1) penyaluran (transmisisi yang baik akan menghasilkan implemntasi yang baik pula kejelasan), (2) adanya kejelasan yang diterima oleh pelaksana kebijakan dan (3) adanya konsistensi yang diberikan dalam pelaksanaan kebijakan. Jika yang di komunikasikan berubah-ubah akan membingungkan dalam pelaksanaan kebijakan yang bersangkutan.

Pelaksanaan komunikasi baik dari internal KPID maupun dengan pelaku penyiaran menggunakan komunikasi dua arah. Terutama ketika melaksanakan monitoring selama penyiaran program musik dangdut. Maksudnya ,diskusi dilakukan antar anggota KPID 
yang berada dalam satu ruangan. Terutama ketika pembicaraan mengenai hasil monitoring berpotensi sebagai pelanggaran isi siaran. Kegiatan komunikasi hanya dilakukan ketika posisi ada dalam kantor KPID, sehingga komunikasi bisa berlangsung selama para anggota KPID melaksanakan monitoring dari ruangkcontrol secara bergantian.

Antara pihak KPID dengan pelaku penyiaran, diberikan kesempatan menyampaikan berbagai permasalahan fungsi pengawasan penyiaran secara menyeluruh dan berkelanjutan. Komunikasi mutlak perlu dilakukan setiap saat selama proses implementasi. Model komunikasi diperlukan baik berupa bahasa lisan maupun tindakan antara KPID dan pelaku penyiaran. Tidak sampai disitu komunikasi antara KPID Jawa Timur dengan KPI Pusat yaitu ketika membicarakan mengenai press maka, pasti berbenturan dengan keberadaan industri besar. Maksudnya, pelaksanaan UU penyiaran pasti berbenturan dengan kepentingan bidang industri penyiaran seperti atauran dianggap tidak relevan lagi sehingga memerlukan revisi secepatnya.

Tuntutan revisi peraturan bukan memerlukan waktu sedikit namun waktu tidak menentu. Kondisi inilah menuntut adanya komunikasi menyeluruh dan berkelanjutan.Namun ketika KPID Jawa Timur sebagai lembaga independen, di satu sisi harus menanggapi pengaduan dari masyarakat, namun di lain sisi menghadapi tantangan kepentingan industri penyiaran. Dua kondisi berbeda inilah maka, terkadang ada benturan atau ketidaksesuaian kepentingan terutama mengenai industri penyiaran. Sehingga pada akhirnya antara bidang pengawasan isi siaran dengan penindakan dipisah. Sebelum dipisah terjadi terjadi kerancuan antara pelanggaran isi siaran dan bidang penindakan.Tujuan pemisahan dua bidang besar di KPID Jawa Timur, supaya masing-masing bidang bisa lebih berkonsentrrasi saat melakukan tindakan semua isi penyiaran berpotensi pelanggaran.

Selain supaya masing-masing bidang bisa lebih berkonsentrasi terutama malakukan tindakan terhadap semua pelanggaran isi penyiaran, alasan optimalisasi peran KPID Jawa Timur menjadi tujuan utama dalam pemisahan respon terhadap segala bentuk pelanggaran isi siaran. Sehingga sering disebut "daya ledak" masing-masing peran bidang penyiaran menjadi lebih besar. Jika pengaruh lebih besar mengenai peran KPID maka, kesempatan dalam menekan tingkat pelanggran terhadap isi penyiaran akan semakin besar serta optimalisi penindakan segala bentuk pelanggaran akan lebih maksimal.

Seberapa besar usaha meningkatkan pengaruh KPID Jawa Timur dalam merepson pelanggaran isi siaran, perlu diperhatikan yaitu ketersediaan alat dan tenaga monitoring selama program musik dangdut disiarkan menjadi kendala jelas di depan mata. Kondisi hambatan ini misalnya standar dalam melakukan monitoring, yakni harus ada beberapa layar televisi, dimana masing-masing layar seharusnya hanya bisa digunakan satu siaran program musik dangdut. Serta masing-masing layar monitoring harus ada satu orang tenaga monitoring profesional. Kenyataannya hanya ada satu layar monitor, dan satu orang pelaksana monitoring. Kondisi inilah dalam menjalankan komunikasi jelas menjadi tantangan sendiri bagi pihak KPID Jawa Timur. Terutama ketika ada beberapa program musik dangdut ditayangkan secara bersamaan baik dari waktu dan durasi penyiaran sama. Maka konsekuensi harus diterima KPID Jawa Timur yaitu ada beberapa potensi pelanggaran terlewatkan dari program musik Dangdut.

Pasalnya keterbatasan antara program yang harus dimonitoring dengan konsentrasi petugas monitoring serta peralatan yang tersedia. Tuntutan monitoring harus dilakukan secara bersamaan dengan knsentrasi tinggi, sedangkan tenaga monitoring tidak bisa membagi konsentrasi pada beberapa program yang ditayangkan bersamaan. 
Keterbatasan dalam menangani tenaga monitoring di KPID Jawa Timur, membuat monitoring di ruang kontrol tidak berjalan maksimal. Selain memang keterbatasan alat dan tenaga monitoring, tenaga monitoring yang tersedia bukan hanya konsentrasi pada layar monitor namun masih ada tugas pribadi seperti tugas kuliah masing-masing pegawai. Kondisi peralatan dalam melakukan monitoring hanya ada satu layar monitor dengan cara dibagi pada beberapa program ditayangkan bersamaan. Pola komunikasi dalam keseharian lebih banyak menggunakan komunikasi kultural antar staff di ruang kontrol ,terutama ketika melakukan monitoring. Tekniknya menggunakan komunikasi pertanyaan tiba-tiba , secara otomatis yang ditanyakan kordinator bidang maka,masing-masing staff akan membuka buku untuk mencari jawaban. Sehingga informasi berpotensi pelanggaran isi penyiaran tidak hanya diperoleh dari satu orang atau sumber saja.

Penjelasan mengenau kondisi iklim komunikasi ini didukung pernyataan Bapak Immanuel Yosua Tjiptosoewarno, M.I.Kom, M.H selaku kordinator bidang penindakan pelanggaran isi siaran (P2IS), yaitu :

" Komunikasi dengan staff dengan pertanyaan tiba-tiba saya munculkan, jadi mau tidak mau harus membuka buku karena kawan-kawan ini susah karena harus membantu di bidang administrasi dan tidak fokus selain itu harus fokus dalam bidang monitoring, kedua kawan-kawan ini masih kuliah dan masih ngurusi tugas kuliah".

Lain halnya ketika berbicara khusus mengenai fungsi KPID, dimana ketika pelaksanaakna fungsi pengawasan lebih banyak menghadapi tantangan dengan pencari keuntungan dan penegakan aturan pengawasan penyiaran suatu program. Tidak sampai disitu, penindakan dilakukan dengan melibatkan pelaku penyiaran, dimana akhir dari penindakan ada berbentuk teguran saja sampai pada pemanggilan pelaku penyiaran. Namun kenyataan di lapangan masih banyak benturan yang terjadi yakni batasan mengenai bentuk pelanggaran isi penyiaran. Tidak ada kesamaan standar menegenai pelanggaran antara televisi dan radio terutama pengaduan potensi pelanggaran dari laporan masyarakat, menyebabkan kesulitan dalam melakukan komunikasi penjatuhan sanksi. Sehingga aKesulitan ini menjadi tantangan tersendiri bagi KPID Jawa Timur pasalnya tidak ada peraturan eksplisit .

Di lain sisi, adanya landasan hukun supaya KPID JawaTimur menaggapi setiap pengaduan masyarakat walaupun pasal belum jelas. Sehingga kondisi tuntutan diharuskannya menaggapi pengaduan pelanggaran isi penyiaran, maka tindakan diambil hanya sebatas teguran, pemberian kesempatan lembaga penyiaran untuk datang ke KPID guna menggunakan hak klarifikasi ketika dinyatakan ada unsure pelanggaran maka akan dibawa ke sidang pleno. Namn sebaliknya ketika tidak ada pelanggaran maka tindakan penjatuhan sanksi hanya sebatas teguran dan peringatan terhadap pelanggaran yang sudah dilakukan.

Berbedanya standar pelanggaran antara televise dan radio terhadap program music dangdut seperti apa yang dinyatakan Kordinator Bidang Penidakan pelanggaran isi siaran , diantaranya:

"Kita ketemu dengan benturan praktis ketika (dominan perilaku penyiaran) permasalahan beda tafsir misal di TV (batas adegan kekerasan apa).erotis music dangdut apa, sering kita pangghil MC. Peraturan eksplisit tidak ada sehingga tidak bisa menjatuhkan sanksi kita hanya menghimbau meminta mereka datang dan diajak diskusi itulah kekuatan pengaduan masyarakat dibandingkan monitoring.(bagian UUP dan P3SPS) Setaip pengaduan masyarakat wajib ditindak 
lanjuti. Walau pasal belum jelas pertama, jelaskan pada pengaduan bahwa ini belum melanggar secara eksplisit, kedua lembaga penyiaran tetap kita panggil dalam proses penanganan pengaduan masyarakat dalam bentuk memberi kesempatan klarifikasi . Disana kalau memang tidak terbukti, ada pelanggaran dari pleno kita tidak ada sanksi minimal ada himbauan”.

\section{Sumber daya}

Implementasi kebijakan mutlak memerlukan dukungan sumbedaya baik sumber daya manusia, matrial dan metoda. Isi, sasaran dan tujuan kebijakan walaupun sudah dikomunikasikan secra jelas dan konsisten, tetapi apabila implementator kekurangan sumber daya untuk melaksanakan, implementasi tidak akan tidak berjalan efektif dan efisien.

Berbicara mengenai sumber daya maka, permasalahan yang dihadapi adalah keterbatasan dana dan pegawai dalam melakukan monitoring secara berkelanjutan. Monitoring memang perlu dilakukan selama 24 jam, namun kenyataannya keterbatasan tenaga membuat semakin sulitnya pihak KPID melakukan pengawasan. Peralatan monitoring mengalami keterbatasan juga pasalanya pengawasan music bukan hanya memerlukan perhatian ke hal suara namun ke visual. Sedangkan kepekaan indra pendengaran dan penglihatan tidak bisa dipecah.

Keterbatasan alat dan tenaga monitoring menjadi halangan utama KPID dalam menjalankan tugasnya terutama menanggapi segala potensi pelanggaran baik dari hasil monitoring maupun pengaduan masyarakat. Keterbatasan dana memang sangat terlihat dengan dihentikannya anggaran oleh pemerintah. Kondisi ini jelas terlihat di KPID Jawa timur, pasalnya kondisi berbeda dengan tahun-tahun sebelumnya memang ada alokasi terhadap kegiatan monitoring, tersedianya tenaga professional monitoring yang memiliki gaji tiap bulannya. Jika kondisi sebe,umnya KPID Jawa Timur tidak terlalu berat menjalankan tugas. Namun kondisi berbeda ketika tidak ada alokasi dana dan terbatasnya tenaga monitoring. Pada akhirnya monitoring dilakukan secara akrobatik, tenaga monitoring hanya mengandalkan mahasiswa magang.

Adanya tenaga magang memang membantu dalam melaksanakan monitoring, namun tetap berbeda dengan KPI Pusat yang memang tenaga monitoring memiliki keterampilan jurnalistik dan memiliki gaji pada tiap bulannya. Keterlibatan mahasiswa magang membuat KPID Jawa Timur harus bekerja keras terutama dalam membimbing mahasiswa supaya paham tata cara monitoring. Mahasiswa magang bukan berada di KPID selama 24 jam, melainkan hanya terbatas waktu dalam tiap harinya. Padahal penyiaran program music dangdut lebih sering dengan jadwal sudah ditentukanm oelh lembaga penyiaran masing-masing. Ketika waktu mahasiswa magang sudah tidak berada di dalam ruangan control, maka disaat itulah terkadang ada potensi pelanggaran luput dari pantauan. Sehingga terkadang KPID Jatim merasa tertinggal dengan pelanggaran terjadi. Sampai terkadang bukan petugas monitoring yang menemukan pelanggaran, namun staff lain diluar fungsi monitoring. Tidak jarang pelanggaran ditemukan mahaiswa magang sdiluar jam magang mereka, sehingga potensi pelanggaran isi siaran tidak bisa direkan yang nantinya akan digunakan sebagai bukti proses penindakan pelanggaran oleh KPID Jawa Timur.

Secara structural, memang sangat jelas kesenjangan antara KPI daerah dengan PUsat. Tenaga monitoring di KPI tingkat Daerah harus melakukan adaptasi mengenai cara menerapkan Undang-undang penyiaran dan P3SPS. Tidak jarang masih awam mengenai 
REFORMASI

ISSN 2088-7469 (Paper) ISSN 2407-6864 (Online)

Volume 8 Nomor 2 (2018)

P3SPS bahkan muncul pertanyaan ketika ada pihak KPI hadir dalam waktu penyiaran program Musik dangdut mengenai apakah itu P3SPS. Permasalahan sumber daya pengawasan ini diperkuat dengan pernyataan bapak Yosua, selaku kordinator bidang penindakan pelanggaran isi siaran yaitu:

"Tenaga monitoring tidak ada, dulu ada 24 jam.Kemudian kita punya tenaga jejaring monitoring yang ditempatkan di beberapa kabupaten dulu ada anggaran. Ketika kami masuk itu semua tidak ada infrasturktur sehingga kita pecah fokusnya monitoring menjadi secara akrobatik. pertama monitoring seperti ini itu kita tidak bisa mengandalkan tenaga dulu sebelum mereka masuk sehingga kami mengandalkan mahasiswa praktek. Mahasiswa praktek membuat kita berjuang setengah mati Memang beda dengan tenaga monitoring khusus yang memiliki salary, kerjaannya memang begitu dan sudah dibekali akan lebih professional. Beda dengan KPI pusat yang memang terdiri dari jurnalis dan produser professional kelas Jakarta .Di tv ini gapnya luar biasa antara Jakarta dengan sini. itu akhirnya kita evaluasi kemudian kita punya kurikulum sederhana misalnya pengenalan singkat mengenai pengenalan UUP dan P3 SPS".

\section{Disposisi.}

Suatu disposisi dalam implementasi dan karakteristik, sikap yang dimiliki oleh implementator kebijakan, seperti komitmen, kejujuran, komunikatif, cerdik dan sifat demokratis. Disposisi yang baik harus dimiliki implementator supaya bisa menjalankan kebijakan dengan baik seperti apa yang diinginkan dan ditetapkan pembuat kebijakan.

"Disposisi. Terkait isi siaran ketika bidang penidakan dan sanksi tidak disendirikan maka gaung untuk efek jeranya lemah. Lalu konsentrasi kita, mau apa mau menegakkan aturan itu kurang optimal ketika itu tidak dipisah. Ketika dipisah menjadi hal menarik, khusus bidang penindakan ada fungsi data yang masuk pengaduan atau potensi pelanggaran munculnya dari dua, pertama monitoring dilakukan dan pengaduan masyarakat . Ketika pengaduan pengaduan masyarakat ketika tidak dipisah itu seolah-olah menyatu jadi kita mau menginisiasi pengaduan masyarakat itu juga tidak optimal. Lalu kita mau mengoptimalkan montoriing kita menjadi lemah. Preofesional dan staff yaitu setiap orang bisa merekam setiap orang menggunakan hp yang ada tvnya. Penindakan kita manfaatkan mahasiwa kita simulasikan sebagai pelapor shingga stelah keluar maka mereka akan menjadi pelapor potensi. Kita gandeng temen pemerhati media dan media watch salah satunya Jatim Media Watch. Pengawasan music dangdut jelas pasal 32 UU tahun 2008 . ada bebertapa lagu yang kita amati dan kita agak terlambat karena lagu tersebut sudah viral lagu "jaran goyang" karena lagu itu termasuk lagu mistikisme.

Masukan dari masyarakat (pasal 85)-P3 mengatur lembaga penyiaran, kalau yang selalu muncul lembaga penyiaran. tetapi SPS merupakan menyangkut isi program siarannya. Awal yang mendapatkan sanksi nya adalah program siarannya namun yang bertanggungjawab dan menjalankan sanksi adalah lembaga penyiaran sebagai penanggung jawab dari program siaran. Tapi objek nya program siarannya sehngga di SPS akan ketemu program siaran. Misalnya dangdut, kita sbelumnya melakukan evaluasi beberapa lagu , kemarin memang muncul beberapa lagu. Tiap tahun dangdut berulang, kita sampai pada titik diskusi apakah lagu lama seperti lagunya Jupe "Belah Duren" kita masukkan lagi atau tidak atau kita bikin lagu yg betu-betul baru. Lagu yang baru keluar tahun ini ,tapi ternyata kesimpulan sementara kita sehrusnya.Namun kami belum melakukan kita akan release yang memang tahun ini daftar lagu yang dilarang dan dibatasi. Lagu sekarang lebih lihai 
cntonya Via Vallen "Temen Tidur" jika dilihat dari kata-katanya ada " aku kedinginan" dll, tarakhir ada kata penghulu sehingga merusak lagu sehingga kita tidak bisa memberikan sanksi. Awalnya memang bernuansa hasrat seksualitas apalagi dengan suara, jadi kita mengamati pelanggaran dangdut yang berbau pelanggaran terkait seksualitas .contohnya beberapa penyanyi selain syairnya ,misalnya desahan-desahan mengarah ke situ . Problem kita ini apa cntohnya lagu "hamil Duluan, Cinta Satu Malam syairnya sudah begitu tapi itu ditambahain lagi, namun kita akan ketemu dengan beberapa lagu yang syairnya disempretkan jadi sing apik. Tapi ada desahan-desahan yang larinya ke situ. Pengaturan tentang lagu (pasal 20).

Kalau misalnya lagu tersebut dasarnya apa kita ada P3 dan SPS yang ideal itu ada landasan asas dan fungsi dan aransemen ada hal yang praktis biasanya berbicara soal kekerasan SARA ,seksualitas ekpspoitasi pada perempuan,. Teknis namun lebih mendasar, namun ada yang teknis lagi. Misalnya lagu itu dilarang (pasal 20 atau 53). Ini salah satunya yang memang eksplisit pada 20 ini khusus tentang lagu, ada kalimat kesopnanan, norma kesopnaan ini kita langsung tembak disini yaitu muatan seks dan lagu dan video. Tapi ada juga yang berbentuk ungkapan kasar dan makian lagunya Dalang Poer "kuduh misuh", Sujiwo Tejo "jancok". Kita sempat ngobrol dengan KPID Bali dan Jawa Tengah. Kalau kita berbicara tentang dangdut ada yang lagu memang betul dangdut dan ada lagu yang didangdutkan. Lagu Sujiwo Tejo kita trerhalang kata "Jancok" tidak ada dalam kamus, namun lembaga penyiaran lagu ini terlalu vulgar. Tapi kalau lagu ini disetel kalau mereka nuntut kita pasti kalah, namun kita masih ada norma kesopanan dimana kata" jancok" merupakan kata masih tabu.Kedua, eksplisit pasal 20 atau muatan seks dalam lagu dank lip video. Satu-satunya yang mengatur soal lagu. Ada tabrakan terminologi berbeda misalnya mengenai kekerasan, ada yang menganggap kekerasan verbal maupun ada yang menganggap kekerasan non verbal. Misalnya kekerasan fisik. Pasal itu kami gunakan untuk menjerat). Lagu "mabuk lagi”. Norma kesopanan ( pasal karet). Pasal 30 harus diterjemahkan (larangan mistikisme, jaran goyang),KPID kebobolan terlalu viral, tapi kita mencari moment, memiliki mistikisme tinggi. Norma kesopanan dan agama." Pengawasan TV ada live, gubahan bebas, rawan yaitu tv local. Analisis nya perlindungan anak dan remaja lagu "hamil sama setan" "cinta satu malam", Cita Citata "perawan janda". Tahun ini masih verifikasi ulang masih titik diskusi namun ketika pengumuman kita keluarkan kita tidak mempunyai benteng yang kuat, dan mereka punya celah maka kita yang kalah.

\section{Struktur birokrasi.}

Organisasi, menyediakan peta sederhana untuk menunjukkan secara umum kegiatan-kegiatannya dan jarak dari puncak menunjukka status relatifnya. Garis- garis antara berbagai posisi dibingkai untuk menunjukkan interaksi formal yan ditetapkan. Kebanyakan peta organisasi bersifat hirarkis dan menentukan hubungan antara atasan dan bawahan secara diagonal langsung organisasi sebagai melalui lima hal harus tergambar yaitu (a) Jenjang hirarki jabatan- jabatan manajerila yang jelas sehingga terlihat" siapa yang bertanggungjawab kepada siapa", (b) Pelembagaan berbagai jenis kegiatan operasional sehingga nyata jawaban terhadap ertanyaan :"siapa yang" melakukan apa?",(c) Jaringan informasi yang dapat dignakan untuk berbagai kepentingan, baik yang sifatnya 


\section{REFORMASI}

ISSN 2088-7469 (Paper) ISSN 2407-6864 (Online)

Volume 8 Nomor 2 (2018)

instistusional maupun individual,(d) hubungan antara satu sauna kerja dngan berbagai satuan kerja yang lain.(Nawawi, 2007:136-138).

Perbedaan antara struktur birokrasi KPID memiliki pengaruh besar dan enjadi salah satu hal acuan dalam implementasi fungsi pengawasan Undang-undang penyiaran. Sehingga mau tidak mau memang harus ada perombakan dari segi birokrasi. Pasalmya perombaka terhdaap struktur birokrasi akan menjadi pendukung utama dalam menegakkan peraturan isi siaran. Jika suatu konsentrasi tugas pokok tertentu dalam bidang birokrasi sudah terbentuk, maka daya wewenangnya bisa lebih kuat, jika dibandingkan tergabung dalam suatu bagian tugas.

Dalam perjalanannya struktur birokrasi KPID akhirnya mengalami perubahan. Setelah berkomnsutasi dengan KPI Pusat ternyata struktur birokrasi tersebut tidak mengikat.Hasilnya ada pemisahan bidang antara pengawasan isi siaran dengan bidang lainnya. Meskipun demikan masih banyak KPI yang tidak sama struktur birokrasinya terutama dalam pembagian bidang-bidang teretntu. Namun tetap saja ada standar minimal dalam penyusunan birokrasi KPI, normalnya ada ketua, wakil ketua, bidang penyusunan infrastruktur, Penyiaran atau perizinan, bidang pengawasan isi siaran serta bidang kelembagaan. Kelembagaan dan SDM akhirnya dipisah, termasuk di dalamnya bidang literasi dan sosialisasi dan memiliki wewenang masing-masing.

"Birokrasi, Di periode KPID yag sekarang kita bagi dua. Dulu hanya pengawasan isi siaran, lalu setelah evaluasi kita coba konsultasi dengan pusat ternyata yang namanya struktur organisasi bidang-bidang itu tidak mengikat. Jadi ada beberapa KPID yang tidak berbeda selain Jawa Timur ada yaitu Jawa Tengah. KPID Jawa Timur di struktur bisa di cek kalau normalnya Ketua, Wakil Ketua,Bidang Penyusunan infrastruktur Penyiaran atau Perizinan, Bidang Pengawasan isi siaran dan satunya Bidang Kelembagaan. Nah kita kmearin kita bagi bidang kelembagaan dan SDM kita sendirikan, Bidang Literasi dan Sosialisasi kita pisah. Kan itu juga berbicara mengenai diseminasi informasi terkait tupoksi KPID dan pengawasan siaran moniotoring siaran bersama itu kan harus melibatkan semua pihak harus intens.

\section{KESIMPULAN}

Pelaksanaan fungsi pengawasan KPID masih harus menghadapi hambatan dari sisi sumberdaya, sarana prasarana serta tantangan kepentingan industri penyiaran dengan penegakan hokum. Keterbatasan sumber daya baik sarana dan parasarana maupun tenaga pelaksana membuat implementasi fungsi pengawasan KPID terpecah konsentrasi, sehingga menyebabkan tidak maksimalnya proses monitoring penyiaran.Implementasi UU No.32 Tahun 2008 belum maksimal diakibatkan adanya beberapa keterbatasan dan hambatan.

\section{DAFTAR PUSTAKA}

Nawawi, Ismail. 2009. Public Policy Analisis, Strategi Advokasi teori dan praktek. Surabaya: Putra Media Nusantara.

Wahab, Solihin Abdul. 2001. Analisis Kebijaksanaan dari Formulasi ke Implementasi Kebijaksanaan Negara Edisi Kedua. Jakarta: Bumi aksara.

Sunario, Astrid S Susanto. 1991. Komunikasi Pengendalian dan Komunikasi pengawasan. Jakarta: Pustaka Sinar Harapan.

Nawawi, Hadari. 1993. Metode Penelitian Bidang Sosial. Yogyakarta: Gadjah Mada University Press. 


\section{REFORMASI}

ISSN 2088-7469 (Paper) ISSN 2407-6864 (Online)

Volume 8 Nomor 2 (2018)

Idrus, Muhammad. 2009. Metode Penelitian Ilmu Sosial Pendekatan Kualitatif dan Kuantitatif edisii kedua. Jakarta: Erlangga.

H. Frederick, William dalam Dloyana Kesumah dkk. 1995. Pesan-pesan Budaya Lagulagu Pop dangdut dan Pengaruhnya terhadap Perilaku Sosial Remaja Kota. Jakarta: Departemen Pendidikan dan Kebudayaan Republik Indonesia.

Helene Bouvier, Helene. 2002. Lebur! Seni Musik dan Pertunjukan dalam Masyarakat Madura. Jakarta: Yayasan Obor Indonesia.

Kuntowijoyo. 2007. Penjelasan Sejarah (Historical Explanation). Yogyakarta: Tiara Wacana.

Lohanda, Mona. 1991. "Dangdut: Sebuah Pencarian Identitas Tinjauan Kecil dari Segi Perkembangan Historis" dalam Edi Sedyawati dan Supardi Djoko Damono (ed.). Seni dalam Masyarakat Indonesia. Jakarta: Gramedia Pustaka Utama.

N. Weintraub, Andrew. 2010. Dangdut Histories: A Social and Musical History of Indonesia's Most Popular Music. New York: Oxford University Press.

P. Meriam, Alam. "The Antropology of Music" dalam R.M Soedarsono. 1999. Seni Pertunjukan Indonesia di Era Globalisasi. Jakarta: Direktorat Jenderal Pendidikan Tinggi Departemen Pendidikan dan Kebudayaan.

Eriyanto. Indonesia Bergoyang Dunia Kita Goyang Dangdut dan Politik Musik Kotemporer Indonesia. Penelitian Tidak Diterbitkan.

H. Frederick, William. "Rhoma Irama and The Dangdut Style: Aspect Of Contemporary Indonesian Popular Culture", Jurnal Indonesia No. 34, Oktober 1982. Cornell Southeast Asia Program. Cornell University. Indonesia Monogtap Politics.

Khusyairi, Johny Alfian,“Genealogi Dangdut : Senuah Upaya Melacak Keaslian Dangdut, Jurnal Kebudayaan dan Kemasyarakatan Mozaik, Vol. I, No.1, Januari-Juni 2003 Surabaya: Komunitas Kajian Kebudayaan dan Masyarakat (K3M) Fakultas Sastra Universitas Airlangga.

Simatupang, Lono. L. Seni \& Antropologi. 1996. "Dangdut Is Very...Very Indonesia” The Search of Cultural Nationalism in Indonesia odern Popular Music. Buletin Antropologi. Tahun. XI/1996. No. 20. Yogyakarta : Jurusan Antropologi Fakultas Sastra Universitas Gadjah Mada. 